УДК 94:334.713(477)«18/19»

https://doi.org/10.34142/2313-2345.2019.56.03

Вановська I. М., кандидат історичних наук, дочент,провідний науковий співробітник лінгвістичного науково-дослідного управління Військового інституту Київського національного університету імені Тараса Шевченко http://orcid.org/0000-0002-3739-3624

\title{
ЖІНОЧЕ ПІДПРИЕМНИЦТВО ЯК ФАКТОР МОДЕРНІЗАЦІЇ УКРАЇНИ У ДРУГІЙ ПОЛОВИНІ ХІХ - НА ПОЧАТКУ ХХ СТОЛІТТЯ
}

У статті розглядаються динаміка, загальні умови і регіональні особливості становлення та розвитку жіночого підприємниитва в Наддніпрянській Украйні у другій половині XIX - на початку XX ст. Підкреслюється, щзо дослідження підприсмницької діяльності украӥнського жіноцтва у другій половині XIX - на початку XX cm. необхідне для сучасної практичної діяльності у справі виявлення $i$ збереження народних трудових навичок і етноначіональних гендерних традицій, подальшого використання їх для відродження в Україні різноманітних традиційних і перспективних видів жіночого підприємництва. Особлива увага приділяється правовому статусу украӥнських жінок-підприємиів та значущості внеску жінок-підприсмниць у прочес економічної модернізаиії дорадянської Украӥни, проте зазначається, що суспільство неоднозначно ставилося до прагнення жінок до публічної громадської діяльності, професійної рівноправності, бо ие завдавало удару по історично сформованим традиційним правилам поведінки. Однак участь жінок у підприємницькій діяльності вже сприймалася суспільством як щось природне, особливо у складній особистій ситуаиії, як жсттєва необхідність. Отже, в пореформену епоху украӥнському суспільству вдалося перебороти стереотипи традиційної патріархальної культури $і$ виробити нову філософію й нормативну базу жіночого підприємництва.

Ключові слова:жіноче підприємництво, гендерний підхід в економіці, правовий статус жінки, економічна модернізачія, жіночі промисли і ремесла.

The article considers the dynamics, general conditions and regional features of the formation and development of women's entrepreneurship in Dnieper Ukraine in the second half of the XIX - early XX centuries. It is emphasized that the study of entrepreneurial activity of Ukrainian women in the second half of XIX - early XX centuries. necessary for modern practical activities in the field of identification and preservation of folk work skills and ethno-national gender traditions, their further use for the revival in Ukraine of various traditional and promising types of women's entrepreneurship. Based on the analysis of various sources related to the study of Ukrainian socio-economic history, the historical conditions of the formation of women's entrepreneurship in Ukraine are determined, the main stages of the formation of different types of women's entrepreneurship are analyzed. The main spheres of women's economic activity, the structure of enterprises, the forms of their socio-economic organization and the main business strategies are studied in detail. Particular attention is paid to the legal status of Ukrainian women entrepreneurs. Based on the researched material, a conclusion is made about the significant contribution of women entrepreneurs to the process of economic modernization of pre-Soviet Ukraine. It should be noted that everywhere in Ukraine the greatest irritation in society was caused by the desire of women for public activity, professional equality, that is, what struck a blow to the historically established traditional rules of conduct. In turn, women's participation in entrepreneurial activity, which took place in the pre-reform period, was perceived by society as something natural, especially in a difficult personal situation, perceived as a vital necessity, a woman's desire to provide a decent life for themselves and their children. This showed that in the post-reform era, Ukrainian society managed to overcome the stereotypes of traditional patriarchal culture, abandon old social stereotypes and develop a new philosophy and regulatory framework for women's entrepreneurship.

Key words: women's entrepreneurship, gender approach in economics, legal status of women, economic modernization, women's crafts and handicrafts.

Постановка проблеми зумовлена тим, що в наш час вивчення історичного досвіду підприємництва є однією з найбільш актуальних проблем соціально-економічного ро- звитку Наддніпрянської України у другій половині XIX - на початку XX ст. При цьому істотний науковий інтерес становить вивчення гендерних аспектів цієї проблеми, 
зокрема, ролі жінок у підприємницькій діяльності в період модернізації українського суспільства. Дослідження історичного досвіду становлення й розвитку протягом другої половини XIX - початку XX ст. жіночого підприємництва у найрізноманітніших сферах української економіки $\epsilon$ сьогодні актуальною темою української історичної науки і становить значний науковий і практичний інтерес. Наукове вивчення жіночого підприємництва дозволяє нам значно збагатити не лише історію України, але й такі галузі вітчизняної науки, як історія народного мистецтва, культурологія, етнологія, історична регіоналістика, соціальна педагогіка тощо. Дослідження теми жіночого підприємництва дозволяє зробити висновки про те, наскільки тогочасному українському суспільству вдалося перебороти стереотипи традиційної патріархальної культури, відмовитися від старих суспільних установок і виробити нову ціннісно-нормативну базу. Особливу роль у цій темі відіграє процес трансформації в пореформений час суспільної свідомості основної частини українського населення в питаннях, що стосуються соціального статусу жінки та $\dddot{11}$ ролі в українському суспільстві. Протягом другої половини XIX - початку XX ст. етнічна ідентичність і ментальність українського народу формувалася, в тому числі, на основі ціннісних переваг відображених у різних формах жіночого підприємництва.

Аналіз актуальних досліджень свідчить, що протягом другої половини XIX початку XXI ст. найбільш суттєвий внесок у наукову розробку питання розвитку жіночого підприємництва в пореформену епоху зробили С. А. Антонович, Р. В. Захарчук-Чугай, М. Є. Станкевич, Є. В. Арофікін, П. Ганжа, С. Ю. Барсукова, М. М. Баришников, О. Боряк, Л. Вагіна, Н. В. Юрина та інші, роботи яких вирізняються постановкою проблеми, насиченістю фактичним матеріалом, вивченням деяких важливих аспектів динаміки жіночого підприємництва в Наддніпрянській Україні протягом другої половини XIX - початку XX ст. Проте дослідження нашої проблеми на сьогодні не можна вважати завершеним.
Мета статті полягає в комплексному дослідженні динаміки, загальних закономірностей і регіональних особливостей становлення й розвитку жіночого підприємництва в Наддніпрянській Україні в контексті соціально-економічної модернізації та етнокультурного розвитку цього українського регіону протягом другої половини XIX початку XX ст. Реалізація поставленої мети досягається шляхом розв'язання низки взаємозалежних і в той же час самостійних наукових завдань, а саме в аналізі факторів розвитку жіночого підприємництва, визначенні його основних форм, соціальноекономічної організації та географії.

Наукова новизна одержаних результатів полягає в тому, що представлена стаття є однією з перших спроб всебічного комплексного наукового вивчення історії становлення й розвитку жіночого підприємництва та пов'язаних із ним соціальноекономічних, гендерних і традиційно-побутових відносин у Наддніпрянській Україні у другій половині XIX - на початку XX ст. При цьому представлена робота будується на широкому колі конкретно-фактичних матеріалів 3 історії жіночого торговельного та виробничого підприємництва. Новим $\epsilon$ концептуальний підхід до вивчення обраної проблеми, який принципово відрізняється від того, що панував в історичній науці за радянських часів. До новизни роботи також цілком можна віднести широке використання в ній i, відповідно, включення в науковий обіг цілої групи нових, маловідомих раніше конкретно-фактичних матеріалів.

Виклад основного матеріалу. Протягом другої половини XIX - початку XX ст. в Наддніпрянській Україні, як і в цілому в Російській імперії, значно активізувався процес економічної модернізації та соціальної трансформації суспільства. Одночасно $з$ цим відбувався процес зміни стану жінок у різних сферах громадського життя. На розвиток цього процесу значно впливав західноєвропейський фемінізм, що поширився на українських землях у ході європеїзації українського суспільства. Соціальні потрясіння пореформеної епохи викликали різноманітні прецеденти розширення прав жінок - у питаннях вибору професійної діяльності, доступності освіти, у тому числі й 
вищої. Політика російського уряду, спрямована на стимулювання вітчизняної економіки, сприяла подальшому розвиткові передових інститутів ринкової економіки в країні. Найважливішим результатом цього процесу став бурхливий розвиток приватного підприємництва, зокрема й різних форм жіночого підприємництва [Денисюк 1916: 171-173]. За приблизною оцінкою, до кінця XIX ст. участь українських жінокпідприємців в економічній сфері досягла рівня від $15 \%$ до 20\%, і це відігравало важливу роль у модернізації як України, так i Російської імперії в цілому. Українські жінки прагнули насамперед ліквідувати своє гендерне відставання від чоловіків, намагалися домогтися успіху, високого соціального статусу й довести наявність не менших особистісних можливостей для досягнення успіху в будь-який іншій виробничотрудовій діяльності [Военно-статистическое обозрение 1891: 291-295].

Особливість правового положення жінки в пореформеній Наддніпрянській Україні полягала в тому, що, відіграючи в соціальному житті традиційну роль дружини, матері, господині будинку, вона водночас могла мати самостійний статус власника i керівника підприємництва: могла займатися, наприклад, кустарним виробництвом і продажем текстильних виробів, а весь прибуток залишати собі [Тихомирова 1999: 34-46]. Ключову роль у виникненні значного шару жінок-підприємців відіграло тогочасне шлюбне законодавство в питанні про роздільну власності чоловіка і жінки. За російськими законами другої половини XIX - початку XX ст. кожна жінка могла мати й здобувати свою окрему власність через купівлю, подарунок, спадщину або в інший законний спосіб. Принцип роздільності власності у шлюбі давав жінці майнову самостійність. Але в той же час особисті правовідносини характеризувалися юридично зафіксованою залежністю замужніх жінок від чоловіка, а дочок - від батьків. Особиста залежність виявлялася в тому, що дружина не могла жити окремо від чоловіка, найматися в служіння й на іншу роботу без дозволу чоловіка, давати на себе векселя, домагатися розлучення [Ежегодник промышленности 1912: 45-47]. Цей пара- докс був причиною несхожості української моделі жіночого підприємництва 3 європейською моделлю, оскільки парадигма правового регулювання була іншою. Усе це позначалося на господарському житті українських жінок, особливо в невеличких містах i селах, та безпосередньо впливало на їхню участь у підприємницькій діяльності [Арофікін 1983: 42-45].

Слід зазначити, що динаміка участі жінок в економічному житті у другій половині XIX - на початку XX ст. відставала від аналогічного показника у чоловіків. Це пояснювалося багатьма причинами: традиційним становищем жінки у провінційному суспільстві, низьким рівнем освіти і професійної підготовки, невисоким рівнем фінансової культури, відсутністю соціальних зав'язків. При цьому підприємницька самоідентифікація жінок грунтувалася на таких чинниках: усвідомлення повної самореалізації особистих здібностей і талантів незалежно від віку; упевненість у тому, що підприємництво дає жінці основу для самоствердження в суспільстві та для досягнення, поряд із чоловіками, значних успіхів у різних галузях економіки; переконаність жінок у високому ступені самостійності, відповідальності, напруженості, ризику при здійсненні управлінської ролі; бажання використати результати успіхів, отриманих у підприємницькій діяльності, для реалізації сімейно-побутових цінностей; представлення у свідомості жінок підприємництва як форми життєдіяльності [Историко-статистический обзор 1889: 419120]. Протягом другої половини XIX - початку XX ст. сотні жінок змогли зреалізувати проголошене в законодавстві Російської імперії право на заняття комерцією нарівні із чоловіками й увійти в групу економічно активного населення. Головним імпульсом до цього був контроль жінок над власністю. Контроль над власністю робив жінок незалежними в розпорядженні майном і веденні будь якого виду підприємства, а також давав можливість активного партнерства із членами родини, головним чином, дорослими синами. В Україні жінки, особливо вдови, часто ставали фактичними главами господарств і зберігали підп- 
риємницькі династії [Кустарная промышленность 1913: 385-388].

Повсюдно в Україні жінки-підприємці займалися в основному дрібним торговим і промисловим виробництвом. Жінки могли володіти дрібними, рідше середніми, підприємствами: водяними млинами, скляними, цегельними, крохмальними, свічковими, шкіряними, хімічними, винокурними й пивоварними заводами [Всероссийские кустарные 1916: 16-20]. Надзвичайно рідко можна було зустріти жінок серед менеджменту великих промислових підприємств. У галузі торгівлі серед жінки-підприємців була поширена роздрібна торгівля різноманітним асортиментом продовольчих товарів, зокрема хлібом, молоком і молочними продуктами, рибою, м'ясом і ковбасними виробами. Чимало жінок було зайнято торгівлею непродовольчими товарами, зокрема галантереєю, шкіряними виробами, тютюном та іншим [Журнал Совещания 1911: 21-22]. Розпочавши 3 дрібних роздрібних торговельних крамниць, жінки - відповідно до вимог часу - стали заводити магазинну торгівлю, особливо у сфері торгівлі непродовольчими товарами. Магазини орієнтувалися на більш показних і платоспроможних клієнтів, їхні приміщення відрізнялися в кращий бік - більшим простором, спеціальним торговельним устаткуванням, асортиментами товарів і сервісом. Проте продовольчі продукти і дешевий крам українське населення продовжувало купувати у дрібних крамницях. В основному роздрібні торговельні підприємства були прив'язані до місцевого ринку й орієнтувалися на попит конкретних споживачів, іноді в межах однієї вулиці чи кварталу. При цьому оптові торговельні операції, в яких брали участь жінки-підприємці, найчастіше були винятком і являли собою разові великі угоди роздрібного товарообігу. Власниці невеликих торговельних підприємств або особисто здійснювали торгівлю, або контролювали роботу своїх закладів, або наймали робітників, що торгували за спеціальним дорученням й одержували за роботу платню чи відсоток прибутку. У магазинах і торгових мережах управлінські функції виконували спеціально найняті прикажчики [Ежегодник главного управления 1912: 311-314].
Незважаючи на те, що в галузі торгівлі основна частина українських жінок-підприємців не піднімалася вище роздрібної та магазинної торгівлі, деякі 3 них досягали значних успіхів, очолюючи великі торгові мережі. Право ведення такої масштабної комерційної діяльності жінками обгрунтовувалося в Російській імперії законодавчо. За законами про осіб купецького звання, керівництво справами фірми після смерті власника переходило до вдови чи, за відсутності спадкоємців чоловічої статі, до незаміжньої дочки [Женские промыслы 1908: 21-24]. Часто, навіть при активній діяльності дорослих, комерційно досвідчених синів, удови формально й фактично вели справи [Петров 2017: 116-122].

Протягом другої половині XIX - початку XX ст. у сфері жіночого підприємництва існував і виробничий напрям, що був пов'язаний iз виготовленням специфічних виробів. Найпоширенішою формою жіночої виробничої підприємницької діяльності повсюдно в Україні залишалося мале промислове підприємництво - кустарні промисли й ремесла. Вони часто мали форму домашнього або сімейного підприємництва. Після скасування кріпосного права та проведення ліберальних реформ, які сприяли початку якісно нового етапу в розвитку традиційних жіночих кустарних промислів і ремесел, утворився широкий простір для їхнього динамічного розвитку, ринкової та соціокультурної трансформації [Материалы для изучения 1872: 36-40].

Саме 3 цього періоду на території українських губерній стали виникати досить великі осередки жіночих промислів і ремесел, що посіли вагоме місце в загальноукраїнському та світовому соціально-економічному просторі. Жіночі промисли та ремесла були одночасно й галуззю кустарної промисловості, і сферою народного мистецтва. Сполучення традицій, стильових особливостей і творчої імпровізації, колективних начал і поглядів окремої особистості, рукотворності виробів і високого професіоналізму були характерними рисами творчої праці майстринь-підприємців. Організаційно-виробничі та художні традиції жіночих кустарних промислів і ремесел склалися в 
Україні ще в дореформену добу [Обзор главнейших отраслей 1899: 29-31].

Феноменальність України, що дала європейській цивілізації таку кількість високорозвинених у якісному відношенні жіночих промислів і ремесел, пояснюється передусім багатими виробничими етнокультурними традиціями українського народу. Жіночі дрібні виробництва другої половини XIX - початку XX ст. необхідно розглядати як модель багатоваріантної української культури, а збереження й розвиток цих промислів необхідно розглядати як спосіб відродження української культурної ідентичності в умовах національного відродження. У цей період українські майстрині, які займалися виробництвом та продажем тканин, килимів, кошиків, гончарних виробів та багато іншого, ставили перед собою основною метою збереження української національної ідентичності, традиційної народної культури і мови, популяризації українського історичного досвіду, передачу наступним поколінням українських народних виробничих традицій [Ежегодник народного 1898: 261-262]. Своєю працею народні майстрині переконливо доводили, що українці мають багатовікову культурну спадщину, самобутню традиційну виробничу культуру, яка була сформована на основі професійного мистецтва світового значення. Можна також констатувати, що для України другої половини XIX - початку XX ст. був характерний процес реалізації ідей національного відродження, який також відбувався і шляхом розвитку етнокультурної трансформації жіночого промислового і торгового підприємництва.

На українських землях процес трансформації статусу жінки через іiї професійну діяльність та еволюцію соціальної психології активніше всього відбувався у великих губернських містах, бо традиційно саме в містах жінки відігравали більш значну роль у соціально-культурному житті, ніж на периферії. У губернських містах проживала основна частина найбільш впливової аристократії, фінансово-промислових кланів й інтелігенції. Мешканки губернських міст істотно відрізнялися від провінціалок, що жили в умовах збереження патріархальних традицій і твердої регламентації норм по- водження. Проте у багатьох повітових центрах можна було зустріти своєрідне сполучення столичних тенденцій зміни статусу жінок із характерними для української провінції гендерних пережитків станового суспільства [Труды комиссии 1887: 173175]. В Україні багато купецьких дружин, особливо в невеликих повітових містах $\mathrm{i}$ селах, сприяли розвиткові не лише економічної, але й гуманітарної сфери життя українського суспільства [Обзор экономического положения 1899: 94-97].

Українські жінки, які були зайняті в сфері підприємництва, дуже часто активно займалися громадською та викладацькою діяльністю, надавали підтримку й особисто працювали у виховних закладах, училищах і гімназіях. Жінки-підприємці часто займалися доброчинністю, були членами багатьох благодійних товариств, виступали в ролі постійних піклувальників громадських установ, проводили благодійні акції, влаштовували школи та спеціальні притулки для малозабезпечених верств населення, практичною діяльністю доводили свій патріотизм і любов до своєї батьківщини - України. Вони брали енергійну участь у процесі українського національного відродження, в популяризації української культури і мови, у формуванні етнокультурної та етносоціальної інфраструктури в багатьох містах та селах України [Положение женщин 2006: 211-216]. Подібна діяльність українських жінок-підприємців була дуже вагомою та доречною, вони не просто збільшували реальні можливості, але й дуже часто створювала єдині умови для задоволення культурних і соціальних потреб українського населення, що значно сприяло розвиткові українського національного відродження. В умовах радикального реформування, що відбувалося в Україні протягом другої половини XIX - початку XX ст., докорінно змінювалися суспільні відносини й роль жінки в суспільстві, по-іншому визначалися іiі соціальні функції. Жінка активно залучалася до різних видів життєдіяльності, обумовлених потребами ринкової економіки, у тому числі й у підприємництво. Гендерний аспект ринкових економічних відносин набував особливого значення у зв'язку з тим, що жінки не тільки продовжували залиша- 
тися одним із вирішальних чинників суспільного виробництва в цілому, але й через те, що саме розгортання жіночого підприємництва створювало можливості для нарощування модернізаційного потенціалу української економіки [Статистическое обозрение 1911: 219-220].

Висновки та перспективи подальших досліджень. Проаналізувавши джерела та наукові роботи з історії становлення й розвитку жіночого підприємництва в Наддніпрянській Україні та пов'язаних із ним соціально-економічних, гендерних і традиційно-побутових відносин, можна зробити висновок про те, що друга половина XIX початок XIX ст. були часом активізації модернізаційного процесу, що знайшло своє відображення й в позитивній динаміці різних форм підприємницької активності українського жіноцтва. На цьому етапі свого історичного розвитку жіноче підприєм- ництво відігравало суттєву роль не лише в соціально-економічному, суспільно-політичному й етнокультурному житті України, а й в українському національному відродженні, залишалося його важливим ідентифікатором.

Дослідження розвитку українського жіночого підприємництва в умовах соціально-економічної та культурної модернізації другої половини XIX - початку XX ст., вивчення цінного досвіду життя й діяльності українських ділових жінок, збереження ними духовності й розвитку національної ідентичності, вагомих культурних набутків світового значення сьогодні стає важливим чинником державотворення та духовного відродження України, фактором позитивного впливу на модернізацію соціальноекономічної сфери, розвиток жіночого підприємництва, сприяє розбудові національно-культурного життя.

\section{ЛІТЕРАТУРА}

1. Антонович С.А., Захарчук-Чугай Р.В., Станкевич М.С. Декоративно-прикладне мистеитво. Львів: «Свim», 1992. $271 \mathrm{c}$.

2. Арофікін С.В. Украӥнська народна тканина // Народна творчість та етнографія. 1983. № 4. C. $42-45$.

3. Барсукова С.Ю. Женское предпринимательство: специифика и перспективы // Социс. 1999. № 9. C. 75 .

4. Барышников М.Н. Женшина в структуре российского предпринимательства в начале XX века // Фактыл и версии: Историко-культурологический альманах. СПб.: Международный институт менеджмента. 2001. С. 134-152.

5. Боряк О. Народне ткацтво // Пам'ятки України: Історія та культура. 1998. № 3-4. С. 103-109.

6. Вагіна Л. Унікальні вироби у музеї етнографії народів СРСР // Народна творчість та етнографія. 1968. № 4. С. 78-83.

7. Статистическое обозрение Российской империи. СПб.: Департамент Ген. итаба, 1911. 529 с.

8. Всероссийские кустарные выставки // Вестник кустарной промышленности. Ежемесячный журнал, издаваемый постоянным бюро Всероссийских съездов деятелей по кустарной промышленности. Пг.: Тип «Энергия». 1916. №15. С.16-20.

9. Ганжа П. Таємниці українського рукомесла. Київ: Мистецтво, 1996. 190 c.

10. Денисюк Н. Ф. Хозяйственная жизнь России. Экономическая география России. Пг.: Изд-во. П. Луковникова, 1916. 279 c.

11. Ежегодник главного управления землеустройства и земледелия по Департаменту земледелия. Год шестой 1912. СПб.: Тип. В. Кирибаума, 1912.429 c.
12. Ежегодник народного труда / под. ред. В. В. Черняева.М. : Тип. И. Д. Сытина, 1898. 461c.

13. Ежегодник промышленности и торговли. СПб.: Tun. B. Киршбаума, 1912. 271 c.

14. Женские промысль в России // Кустарь. 1908. №2. C. 21-24.

15. Журнал Совещзания о нуждах кустарной промышленности. СПб.: Тип В. Киршбаума, 1911. $90 \mathrm{c}$.

16. Историко-статистический обзор промышленности России. СПб.: Тип. В. Киршбаума, 1889. $528 \mathrm{c}$.

17. Кустарная промышленност в России. Женские промысльь. СПб.: Тип. «Якорь», 1913. 440 с.

18. Материаль для изучения кустарной промыиленности и ручного труда в России / [cocm. Л. Майков]. СПб. : Центр. стат. комитет МВД, 1872. Ч. $1361 \mathrm{c}$.

19. Обзор главнейших отраслей промьлиленной деятельности в 1898 г. СПб.: Изд-во торговопром. газеты. 1899. $68 \mathrm{c.}$

20. Обзор экономического положения России в сельскохозяйственном и промышленном отношении. СПб.: Тип. С.Т. Цветков, 1899. 121 с.

21. Петров Ю. А. Деловые женщиины // Вестник С.Петербургского университета. 2017. № 2. C.116-122.

22. Положение женщин в правовом поле Российской империи на рубеже $X I X-X X$ вв.: публикация законодательных актов. СПб.: Б.и., 2006. 342 c.

23. Тихомирова М. Н. Участие женщиин в промылленном производстве России в конце 60 - начале 70 годов ХІХ века // Женщиньл. История. Общество. Тверь: ТвГУ, 1999. С. 34-46. 
24. Труды комиссии по исследованию кустарной промышленности в России. - СПб.: Тип. В. Кирибаума, 1887. T. 16. 605, 100, 251 c.

25. Юрина Н.В. Женское предпринимательство в провинциальных городах (вторая половина XIX- начало ХХ вв.) // Сочиальная история российской провинции в контексте модернизации аграрного общества в XVIII-XX вв.: материаль международной конференции (май 2002 г.). Тамбов :ТГУ, 2002. $341 \mathrm{c}$.

\section{REFERENCES}

1. Antonovich S.A., Zakharchuk-Chugai R.V., Stankevich M.E. Decorative and applied arts. Lviv: Svit, 1992. 271 p. [in Ukrainian].

2. Arofikin E.V. Ukrainian folk fabric // Folk art and ethnography. 1983. № 4. P. 42-45.

3. Barsukova S.Yu. Women's entrepreneurship: specifics and prospects // Socis. 1999. № 9. P. 75. [in Russian].

4. Baryshnikov M.N. Woman in the structure of Russian entrepreneurship in the early twentieth century // Facts and versions: Historical and cultural almanac. St. Petersburg: International Institute of Management. 2001. P. 134-152. [in Russian].

5. Boryak O. Folk weaving // Sights of Ukraine: History and culture. 1998. № 3-4. P. 103-109. [in Ukrainian].

6. Vagina L. Unique products in the Museum of Ethnography of the Peoples of the USSR // Folk Art and Ethnography. 1968. № 4. P. 78-83. [in Ukrainian].

7. Statistical review of the Russian Empire. SPb.: Department of Gen. headquarters, 1911. 529 p. [in Russian].

8. All-Russian handicraft exhibitions // Bulletin of the handicraft industry. A monthly magazine published by the permanent bureau of the All-Russian Congresses of Artisans. Pg.: Type «Energy». 1916. №15. P.16-20. [in Russian].

9. Ganzha P. Secrets of Ukrainian handicrafts. Kyiv: Art, 1996. 190 p. [in Ukrainian].

10. Denisyuk NF Economic life of Russia. Economic geography of Russia. Pg.: Izd-vo. P. Lukovnikova, 1916. 279 p. [in Russian].

11. Yearbook of the Main Department of Land Management and Agriculture of the Department of Agriculture. Year six 1912. St. Petersburg: Type. W. Kirschbaum, 1912. 429 p. [in Russian].

12. Yearbook of People's Labor / under. ed. V.V. Chernyaeva. M.: Type. ID Sytina, 1898. 461 p. [in Russian].

13. Yearbook of Industry and Trade. SPb.: Type. W. Kirschbaum, 1912. 271 p. [in Russian].
14. Women's crafts in Russia // Artisan. 1908. №2. P. 21-24. [in Russian].

15. Journal of the Handicraft Needs Meeting. SPb.: Type V. Kirshbauma, 1911.90 p. [in Russian].

16. Historical and statistical review of Russian industry. СПб.: Tun. W. Kirschbaum, 1889. 528 p. [in Russian].

17. Handicraft industry of Russia. Women's crafts. СПб.: Tun. "Anchor", 1913. 440 p. [in Russian].

18. Materials for the study of handicrafts and manual labor in Russia / [comp. L. Maikov]. СПб. : Center. stat. Committee of the Ministry of Internal Affairs, 1872. Part 1. 361 p. [in Russian].

19. Review of the main branches of industrial activity in 1898. St. Petersburg: Publishing House of Trade and Industry. newspapers. 1899. 68 p. [in Russian].

20. Review of the economic situation in Russia in agricultural and industrial terms. SPb.: Tip. S.T. Tsvetkov, 1899.121 p. [in Russian].

21. Petrov Yu.A. Business women // Bulletin of St. Petersburg University. 2017. № 2. P.116-122. [in Russian].

22. The position of women in the legal field of the Russian Empire at the turn of the XIX-XX centuries: the publication of legislation. SPb.: B.i., 2006. 342 p. [in Russian].

23. Tikhomirova M.N. Participation of women in industrial production in Russia in the late 60's and early 70's of the XIX century // Women. History. Society. Tver: TvSU, 1999. P. 34-46. [in Russian].

24. Proceedings of the commission for the study of the handicraft industry in Russia. CПб.: Tun. V. Kirshbauma, 1887. T. 16. 605, 100, 251 s. [in Russian].

25. Yuryna N.V. Women's Entrepreneurship in Provincial Cities (second half of the 19th beginning of the 20th centuries) // Social History of the Russian Province in the Context of Modernization of Agrarian Society in the 18th-20th Centuries: Proceedings of an International Conference (May 2002). Tambov: TSU, 2002. 341 p. [in Russian]. 